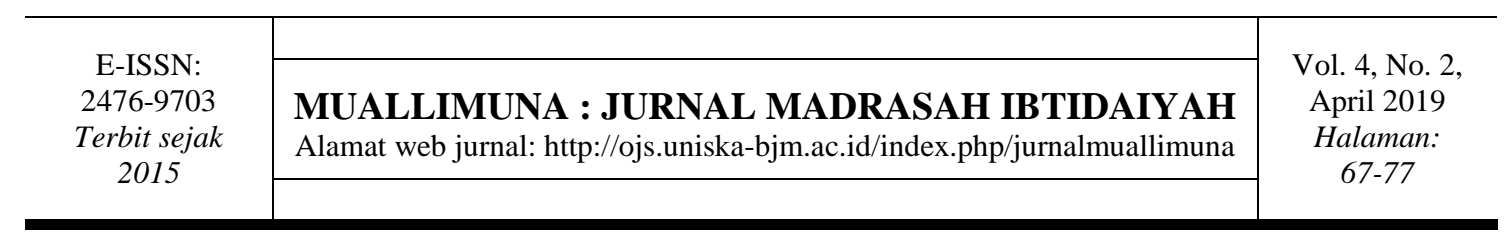

\title{
PEMBELAJARAN BAHASA ARAB BERBASIS KEBUDAYAAN LOKAL MADIHIN UNTUK MENINGKAT HASIL BELAJAR
}

\author{
Mahmudah \\ PGMI, Universitas Islam Negeri Antasari Banjarmasin \\ mahmudah.syifa25@gmail.com
}

\begin{abstract}
Abstrak: Penelitian dengan menggunakan metode yang di adaptasi dari kebudayaan lokal menjadikan pembelajaran yang menarik, selain dapat meningkatkan hasil belajar peserta didik, minat belajar, serta juga menambah wawasan peserta didik mengenai kebudayaan lokal di daerah tempat dia tinggal. Tujuan dari penelitian ini adalah untuk mengetahui bagaimana metode ini dapat meningkatkan hasil belajar peserta didik. Metode penelitian yang digunakan adlah metode penelitian eksperimen jenis pottest only Control dengan subyek penelitian adalah peserta didik kelas IV MIN 9 Banjar. Hasil dari penelitian ini adalah mengolah mufrodat dalam bentuk madihin sangat efektif untuk meningkatkan keberhasilan belajar peserta didik. Hal ini dibuktikan dengan tingkat keberhasilan belajar peserta didik yang cukup memuaskan yang dapat diketahui dari indikator keberhasilan yang berupa nilai hasil belajar peserta didik dan proses pembelajaran. Proses belajar sangat menentukan hasil belajar. Nilai rata-rata hasil belajar peserta didik pada pre-test adalah 56,8, pada tes akhir siklus pertama adalah 77,8 , sedangkan pada tes akhir siklus kedua adalah 81,2. Nilai hasil belajar ini tingkat keberhasilanya berada pada criteria sangat baik. Sedangkan ketuntasan peserta didik pada pre-test adalah 35\%, pada siklus 1 peserta didik tuntas adalah 67,8 dan siklus 2 adalah $78,5 \%$.
\end{abstract}

Kata Kunci: Pembelajaran; Bahasa Arab; Madihin, Kebudayaan Lokal, Hasil Belajar

\section{INSTRUCTIONAL OF ARABIC LANGUAGE BASED ON LOCAL CULTURE MADIHIN TO IMPROVE LEARNING OUTCOMES}

\begin{abstract}
Research using methods adapted from local culture makes learning interesting, in addition to improving student learning outcomes, interest in learning, and also enhances students' knowledge about the local culture in the area where he lives. The purpose of this research is to find out how this method can improve student learning outcomes. Research metods use eksperimen research with Pottest only Control, the subject of research is Student of IV Class MIN 9 Banjar. The results of this study are processing mufrodat in the form of madihin very effective to improve the learning success of students. This is evidenced by the level of learning success of students who are quite satisfying which can be known from the indicators of success in the form of student learning outcomes and learning processes. The learning process greatly determines learning outcomes. The average value of students' learning outcomes in the pre-test was 56.8 , at the end of the first cycle the test was 77.8, while at the end of the second cycle the test was 81.2. The value of learning outcomes is the level of success at very good criteria.
\end{abstract}


While the completeness of students in the pre-test is 35\%, in the first cycle students complete is 67.8 and cycle 2 is $78.5 \%$.

Keywords: Instructional, Arabic Language, Madihin, Local Culture, Local Wisdom, Learning Outcomes

\section{PENDAHULUAN}

Menurut ajaran Islam manusia adalah makhluk yang paling sempurna dan berbeda dengan makhluk lain karena manusia memiliki akal. Untuk itu Islam memerintahkan kepada umat manusia untuk mencari ilmu pengetahuan, sehingga manusia itu sendiri tidak lepas dengan pendidikan dalam kehidupannya untuk memperoleh pengembangan bagi pendidikannya sesuai dengan bakat dan potensi yang dimilikinya.

Dengan demikian, pelaksanaan pendidikan sebaiknya menggunakan teori yang terbukti dan teruji kebenarannya seperti halnya Ki Hajar Dewantara yang berpendapat bahwa, "Pendidikan hendaknya diselenggarakan secara terorganisir antara sekolah, masyarakat dan keluarga yang sangat internal, yang biasanya disebut dengan istilah Tri Pusat Pendidikan. Dalam hal ini tiga elemen pendidikan tersebut sangat diharapkan untuk bertanggung jawab serta membantu peserta didik agar mereka mampu meraih prestasi pendidikan sebagaimana tujuan pendidikan nasional.

Hal itu sesuai dengan salah satu amanat dari UUD 1945 yang mengupayakan untuk mencerdaskan kehidupan bangsa, yang mana dijelaskan dalam Undang-undang nomor 20 tahun 2003 tentang Sistem Pendidikan Nasional bahwa pendidikan nasional bertujuan mencerdaskan kehidupan bangsa dan mengembangkan manusia Indonesia sepenuhnya yaitu manusia yang beriman dan bertakwa terhadap Tuhan Yang Maha Esa dan berbudi pekerti yang luhur, memiliki pengetahuian dan ketrampilan, sehat jasmani dan rohani, berkepribadian mantap dan mandiri serta rasa tanggung jawab kemasyarakatan dan kebangsaan. Sehingga di dalam dasar atau tujuan Pendidikan Nasional disebutkan bahwa, tujuan pendidikan adalah untuk meningkatkan kecerdasan bangsa.

Seorang guru hendaknya tidak hanya menggunakan satu metode saja dalam mengajar. Mengingat penggunaan metode secara bervariasi dapat menghidupkan dan meningkatkan perhatian peserta didik dalam memahami pelajaran. Sehingga dapat dipahami bahwa dengan menggunakan metode yang tepat, bahan pelajaran akan dapat ditangkap, dipahami, dan digunakan oleh peserta didik dengan baik yang pada gilirannya tujuan yang telah dirumuskan dapat tercapai.

Hal yang merisaukan dalam dunia pendidikan adalah masih banyaknya guru yang setia menggunakan metode belajar tradisional yang cenderung menimbulkan kejenuhan pada peserta didik dalam mengikuti pelajaran sehingga akan dapat menimbulkan dampak mempengaruhi hasil belajar. Pada sistem pengajaran yang tradisional, penggunaan sumber pembelajaran masih terbatas pada informasi yang disampaikan oleh guru dan ditambah sedikit dari buku (Suwarna 2005: 115). Jadi metode yang selama ini digunakan guru dalam mengajar dirasa kurang efektif, karena hanya mendengarkan apa yang diucapkan guru, kemudian mencatat dan menghafal sehingga aktivitas belajar peserta didik sangat kurang berkembang.

Berpijak dari pernyataan di atas, maka kemampuan guru untuk menggunakan metode yang tepat dalam mengajar akan menentukan keberhasilan proses belajar mengajar itu sendiri. Sedangkan mengingat metode mengajar jumlahnya relatif banyak, tentu saja penggunaannya disesuaikan dengan tujuan apa yang akan dicapai serta sifat 
dari materi yang akan diberikan. Penggunaan metode yang tepat ini juga bukan ditentukan oleh banyaknya metode atau macamnya metode mengajar yang digunakan.

Menurut Suryobroto (1997: 43) Metode mengajar yang baik adalah metode mangajar yang dapat menumbuhkan kegiatan belajar mengajar peserta didik, serta menggunakan metode mengajar secara bervariasi.Oleh karena itu, seorang guru harus mampu memilih metode mengajar yang sesuai, memenuhi beberapa persyaratan dan ketentuan demi tercapainya tujuan pendidikan, dan memperhatikan respon balik dari peserta didik. Dengan langkah tersebut dapat diketahui kemampuan peserta didik serta kesesuaian metode dengan materi dan keinginan peserta didik, sehingga prestasi belajar peserta didik bisa meningkat. Semakin tinggi dan luas pendidikan dan penguasaan materi yang yang dimiliki guru, baik cara mengajarnya, maupun penampilannya, tentunya akan makin mempengaruhi terhadap mutu pengajarannya. Keberhasilan dalam melaksanakan suatu pengajaran sebagian besar ditentukan oleh pilihan bahan dan pemakaian metode yang tepat (Trigan $1990: 41$ ).

Wagiran (2011). Dalam penelitiannya ditemukan hasil bahwa pendidikan berbasis kearifan lokal sangat perlu diterapkan. Data yang diperoleh menunjukkan bahwa sebagian besar guru $(51,2 \%)$ menyatakan bahwa pendidikan kearifan lokal sangat penting diterapkan, 46,4\% guru menyatakan penting dan hanyar 3 guru $(0,9 \%)$ menyatakan tidak penting. Pernyataan tentang betapa pentingya pembelajaran berbasis keraifan lokal juga dikemukan dan didukung oleh ( Daryanto, 2014.1) bahwa melalui pendidikan, nilai-nilai luhur kebudayaan hendaknya dikenalkan kepada peserta didik serta dapat dikembangkan sehinga peserta didik mampu menjadi pewaris budaya.

Salah satu metode yang menarik untuk di gunakan adalah metode yang berkaitan langsung degan kebudaaan lokal tempat peserta didik tinggal, karena selain kegiatan belajar mengajar menjadi efektif menggunakan metode pembelajaran yang variatif, tentu saja nilai tambah dari penggunaan metode berbasiskan kebudayaan lokal adalah peserta didik menjadi kaya pengetahuan akan budaya lokal di daerahnya sendiri. Budaya Lokal juga diartikan dengan nilai- nilai lokal hasil budi daya masyarakat suatu daerah yang terbentuk secara alami dan diperoleh melalui proses belajar dari waktu ke waktu. Budaya lokal dapat berupa hasil seni, tradisi, pola pikir, atau hukum adat. Salah satu bentuk budaya lokal adalah flokflor yaitu seni budaya yang bersifat lisan, tradisional dan bentuknya berbeda-beda. Menurut Utari ( 2016), kearifan lokal adalah kecendekian terhadap kekayaan setempat/suatu daerah berupa pengetahuan, kepercayaan, norma, adat istiadat, kebudayaan, wawasan, dan sebagainya yang merupakan warisan dan dipertahankan sebagai sebuah identitas dan pedoman kita dalam untuk bertindak secara tepat.

Begitu banyak anak- anak masa sekarang yang kurang mengetahui kebudayaan di daerahnya sendiri, dikarenakan pengaruh budaya modern yang kurang santun menggilas kebudayaan lokal itu sendiri. Anak- anak Kalimantan Selatan khususnya lebih banyak yang tau lagu- lagu barat yang dinyanyikan oleh artis-artis barat, ketimbang seni tradisional Banjar seperti Belamut, Madihin dan kebudayaan lainnya yang dimainkan oleh pelaku seni asal Banjar sendiri.

Salah satu jenis budaya lokal Kalimantan Selatan yang dapat digunakan sebagai metode pembelajaran bahasa arab adalah Madihin. Penggunaan seni lisan dalam Madihin cocok digunakan sebagai metode pembelajaran bahasa Arab dalam materi mufrodat, karena bisa dilantunkan juga dari arti, pelafalan bahasa arab serta nada yang digunakan melalui madihin. 
Istilah madihin berasal dari perkataan bahasa Arab "madah" yang berarti berkatakata, dari kata tersebut jelaslah madihin adalah karya seni budaya Islam dan pengaruh kasidah Arabi, namun telah tercipta dengan bahasa Banjar. Rangkaian syair-syairnya dan pantun yang menjadi bahan komunikasi dan informasi. Kesenian ini tersebar luas di kalangan masyarakat Banjar, menurut Amir Hasan Kiai Bondan, kesenian madihin sudah ada ketika pemerintahan panembahan Sultan Adam di kerajaan Banjar. Madihin merupakan perpaduan antara flokflor lisan dan bukan lisan, karena menggabungkan dua seni, yaitu seni lisan berupa pepatah, nasihat, puji-pujian, dan juga seni alat musik yang digunakan berupa terbang/ rebana.

Di dalam pagelaran madihin, pantun-pantun berfungsi sebagai pembukaan, baturai pantun, pantun pelipur, pantun puji-pujian, pantun jenaka, dan penutupnya.

Madihin (berasal dari kata madah dalam bahasa Arab yang berarti "nasihat", tapi bisa juga berarti "pujian") adalah sebuah genre puisi dari suku Banjar. Puisi rakyat anonim bergenre Madihin ini cuma ada di kalangan etnis Banjar di Kalsel saja. Sehubungan dengan itu, definisi Madihin dengan sendirinya tidak dapat dirumuskan dengan cara mengadopsinya dari khasanah di luar folklor Banjar (Dinas Pemuda dan Olahraga. 2015).

Tajuddin Noor Ganie (2006) mendefinisikan Madihin dengan rumusan sebagai berikut: puisi rakyat anonim bertipe hiburan yang dilisankan atau dituliskan dalam bahasa Banjar dengan bentuk fisik dan bentuk mental tertentu sesuai dengan konvensi yang berlaku secara khusus dalam khasanah folklor Banjar di Kalsel.

Hasil belajar merupakan pencapaian tujuan pendidikan pada peserta didik yang mengikuti proses belajar mengajar. Hasil belajar termasuk komponen pendidikan yang harus disesuaikan dengan tujuan pendidikan, karena hasil belajar diukur untuk mengetahui ketercapaian tujuan pendidikan melalui proses belajar mengajar.

Adapun proses pembelajaran dengan menggunakan metode yang diadopsi dari kesenian khas Banjar inidapat diuraikan sebagai berikut: 1) Memilih materi pelajaran yang cocok. Materi yang dipilih adalah materi mufrodat kelas 4 MI, 2) Setelah memilih materi yang pas, guru membagi kelas menjadi 4-5 kelompok diskusi, 3) Setelah kelompok terbentuk, guru menginstruksikan kepada peserta didik untuk merangkai mufrodat beserta artinya kedalam bentuk sastra lisan madihin. Dengan tenggang waktu yang telah ditentukan, 4) Setelah waktu diskusi habis, masing-masing kelompok menampilkan secara bergantian di depan kelas bentuk seni sastra lisan madihin mufrodat yang telah didiskusikan, dan 5)Guru memberikan penghargaan berupa pujian da lainnya kepada kelompok dengan penampilan terbaik.

\section{METODE}

Jenis Penelitian yang digunakan dalam penelitian ini adalah Penelitian Tidakan Kelas (PTK) yang dalam Bahasa Inggris PTK disebut Classroom Action Research (CAR). PTK sangat cocok untuk penelitian ini, karena penelitian diadakan dalam kelas dalam penelitian ini lebih difokuskan pada masalah-masalah yang terjadi di dalam kelas atau pada proses belajar mengajar.

Peneliti menggunakan model PTK Kemmis \& Mc. Taggart sebagaimana dikutip Jumiati (2017) yang dalam alur penelitiannya meliputi langkah - langkah : 1) perencanaan (plan). 2) melaksanakan tindakan (act), 3) melaksanakan pengamatan (observe), dan 4) mengadakan refleksi / analisis (reflection). Sehingga penelitian ini merupakan proses siklus spiral, mulai dari perencanaan, pelaksanaan tindakan, 
pengamatan untuk modifikasi perencanaan, dan refleksi. Penelitian ini juga merupakan penelitian individual.

Subjek Penelian adalah peserta didik kelas IV MIN 9 Banjar, semester I, berjumlah 20 peserta didik, dengan rincian peserta didik laki-laki 10 anak dan siswi putri 10 anak. Berdasarkan model pengumpulan data, peneliti menganalisa data secara deskriptif, baik deskriptif kualitatif maupun deskriptif kuantitatif. Data yang akan dianalisa secara deskriptif kualitatif berupa data dari hasil pengamatan atau observasi dengan menggunakan intsrumen observasi, sedangkan data yang dianalisis secara deskriptif kuantitatif adalah data tentang hasil tes belajar siswa.

\section{HASIL DAN PEMBAHASAN Paparan Data Pra-Tindakan (Refleksi Awal)}

Dari hasil test pertama dapat diketahui bahwa peserta didik tuntas adalah $35 \%$ dan peserta didik tidak tuntas adalah $65 \%$. Sedangkan rata-rata skor tes awal peserta didik adalah 56,8 .

Kegiatan peneliti selanjutnya adalah menentukan kelompok kemampuan peserta didik dalam kelas eksperimen. Berdasarkan tabel urutan skor tes awal peserta didik, peserta didik dibagi ke dalam tiga bagian, yaitu peserta didik berkemampuan tinggi nomor urut 1 s.d. 6 yaitu sebanyak 6 peserta didik, peserta didik berkemampuan sedang nomor urut 7 s.d. 15 yaitu sebanyak 9 peserta didik, dan peserta didik berkemampuan rendah nomor urut 15 s.d. 20 yaitu sebanyak 5 peserta didik. Pengelompokan peserta didik tersebut selanjutnya digunakan oleh peneliti untuk membentuk kelompok belajar. Peneliti membentuk 4 kelompok belajar dan masing-masing kelompok terdiri dari 5 peserta didik yang dipilih secara acak. Dalam satu kelompok selalu ada peserta didik berkemampuan tinggi, peserta didik berkemampuan sedang, dan peserta didik berkemampuan rendah. Secara detil deskripsi masing-masing kelompok dalam dilihat pada tabel 1 berikut.

\section{Tabel 1. Deskripsi Kelompok Asal Belajar}

\begin{tabular}{|c|c|c|}
\hline \multirow{2}{*}{$\begin{array}{c}\text { Kelompok } \\
1\end{array}$} & \multicolumn{2}{|c|}{ Kode Peserta didik } \\
\hline & 2 & 3 \\
\hline I & $\begin{array}{l}\text { SSS } \\
\text { HMA } \\
\text { RN }\end{array}$ & $\begin{array}{l}\text { ENS } \\
\text { UEP }\end{array}$ \\
\hline II & $\begin{array}{l}\text { MFF } \\
\text { MCR } \\
\text { RAS }\end{array}$ & $\begin{array}{l}\text { DAP } \\
\text { NGP }\end{array}$ \\
\hline III & $\begin{array}{l}\text { MNE } \\
\text { MAR } \\
\text { MSD }\end{array}$ & $\begin{array}{l}\text { MAK } \\
\text { ADK }\end{array}$ \\
\hline IV & $\begin{array}{l}\text { ALK } \\
\text { FZ } \\
\text { MFZ }\end{array}$ & $\begin{array}{l}\text { AMR } \\
\text { KHD }\end{array}$ \\
\hline
\end{tabular}

\section{Paparan Data Pelaksanaan Tindakan (Siklus 1)}

Pelaksanaan tindakan siklus I terbagi kedalam empat tahap, yaitu tahap perencanaan, pelaksanaan, observasi, dan refleksi yang membentuk suatu siklus. Namun dalam paparan data ini peneliti menggambarkan pelaksanaan tindakan siklus 1 sebagai berikut yaitu perencanaan, pelaksanaan, observasi guru, observasi peserta didik, refleksi 
siklus I dan kendala dan rencana perbaikan siklus 1. Masing-masing tahap dapat dijelaskan sebagai berikut.

\section{Tahap Perencanaan}

Pada tahap ini kegiatan yang dilakukan pleh peneliti adalah: 1) Menyiapkan rencana pembelajaran, 2) Menyiapkan materi pembelajaran yang akan disajikan (Mufrodat), 3) Menyiapkan lembar observasi, pedoman wawancara, dan catatan lapangan, dan 4) Melakukan koordinasi dengan guru Bahasa Arab mengenai pelaksanaan tindakan kelas.

\section{Tahap pelaksanaan tindakan}

Pelaksanaan tindakan pada siklus pertama ini dilaksanakan pada hari senin dalam satu pertemuan yang terdiri dari dua jam pelajaran. Kegiatan proses belajar yang dilakukan oleh peneliti pada siklus 1 mengacu pada RPP (Rencana Pelaksanaan Pembelajaran) yang disetujui oleh pihak sekolah. Format RPP Siklus 1.

Tabel 2. Sintak Penerapan Metode Madihin dalam Pembelajaran

\begin{tabular}{|c|c|}
\hline FASE-FASE & PERILAKU GURU \\
\hline $\begin{array}{l}\text { Fase 1: Presents Goals and set } \\
\text { Menyampaikan tujuan dan mempersiapkan } \\
\text { peserta didik }\end{array}$ & $\begin{array}{l}\text { Menjelaskan tujuan pembelajaran dan } \\
\text { mempersiapkan peserta didik siap belajar seperti : } \\
\text { 1. Membuka dengan salam } \\
\text { 2. Mengabsen peserta didik } \\
\text { 3. Memberikan motivasi belajar kepada peserta } \\
\text { didik } \\
\text { 4. Menyampaikan tujuan pembelajaran } \\
\text { 5. Apersepsi : mengingatkan mufrodat } \\
\text { pembelajaran sebelumnya }\end{array}$ \\
\hline $\begin{array}{l}\text { Fase 2: present information } \\
\text { Menyajikan informasi }\end{array}$ & $\begin{array}{l}\text { 1. Mempresentasikan informasi kepada peserta } \\
\text { didik secara verbal materi mufrodat } \\
\text { 2. Membagikan lembar mufrodat }\end{array}$ \\
\hline $\begin{array}{l}\text { Fase 3: Organize students into learning teams } \\
\text { Mengorganisir peserta didik ke dalam tim-tim } \\
\text { belajar. }\end{array}$ & $\begin{array}{l}\text { 1. Memberikan penjelasan kepada peserta didik } \\
\text { tentang tata cara pembentukan tim belajar dan } \\
\text { membantu kelompok melakukan transisi yang } \\
\text { efisien } \\
\text { 2. Guru menentukan jumlah kelompojk } \\
\text { 3. Guru meminta peserta didik untuk } \\
\text { menghitung berurutan sampai 4, peserta didik } \\
\text { yang mendapat angka yang sama akan } \\
\text { membentuk kelompok belajar }\end{array}$ \\
\hline $\begin{array}{l}\text { Fase 4: Assist team work and study } \\
\text { Membantu kerja tim dan belajar }\end{array}$ & $\begin{array}{l}\text { Membantu tim-tim belajar selama peserta didik } \\
\text { mengerjakan tugasnya seperti: } \\
\text { 1. Guru menampilkan contoh penampilan } \\
\text { madihin dalam bentuk video } \\
\text { 2. Guru berkeliling kelas memantau kerja } \\
\text { peserta didik } \\
\text { 3. Setelah peserta didik menguasai mufrodatnya } \\
\text { dan telah membentuk konsep madihin yang } \\
\text { cocok, guru mempersilahkan untuk maju } \\
\text { kedepan kelas secara bergantian. }\end{array}$ \\
\hline $\begin{array}{l}\text { Fase 5: Test on the materials } \\
\text { Mengevaluasi }\end{array}$ & $\begin{array}{l}\text { 1. Guru mengadakan kuis individual dan } \\
\text { meminta peserta didik mengerjakan secara } \\
\text { individual berupa tebakan mufrodat yang } \\
\text { telah dighafal peserta didik }\end{array}$ \\
\hline $\begin{array}{l}\text { Fase 6: Provide recognition } \\
\text { Memberikan pengakuan atau penghargaan }\end{array}$ & $\begin{array}{l}\text { Mempersiapkan cara untuk mengakui usaha dan } \\
\text { prestasi individu maupun kelompok seperti: }\end{array}$ \\
\hline
\end{tabular}


1. Memberi penghargaan kepada kelompok dengan nilai terbaik

2. Membacakan nilai terbaik dalam tes individual

\section{Tahap observasi}

Pengamatan dilakukan oleh dua pengamat, yaitu Yulia Faridah selaku guru Bahasa Arab sebagai pengamat 1 dan Sarniah sebagai pengamat 2. Pengamat bertugas mengamati semua aktivitas guru dan aktivitas peserta didik selama pembelajaran berlangsung. Pengamatan ini dilakukan sesuai pedoman yang telah disediakan peneliti. Jika ada hal-hal penting yang terjadi dalam kegiatan pembelajaran dan tidak ada dalam poin pedoman pengamatan, maka hal tersebut dimasukkan sebagai hasil catatan lapangan. Berdasarkan hasil pengamatan aktifitas peneliti dan peserta didik pada siklus 1, ada beberapa hal yang tidak sempat dilakukan oleh peneliti. Namun secara umum, kegiatan peneliti sudah sesuai dengan rencana yang ditetapkan. Nilai yang diperoleh dari pengamatan tentang aktivitas guru adalah 78, nilai yang diperoleh dari pengamatan tentang aktivitas peserta didik adalah 82, sedangkan skor maksimal adalah 90. Sehingga nilai yang diperoleh rata-rata adalah $\frac{78+82}{2}=80$. Jadi nilai akhir yang didapat adalah: $\frac{80}{90} \times 100 \%=88,88$, yaitu Sesuai taraf keberhasilan tindakan yang ditetapkan, yaitu:

$$
\begin{array}{ll}
90 \% \leq \mathrm{NR} \leq 100 \% & : \text { Sangat Baik } \\
80 \% \leq \mathrm{NR}<90 \% & : \text { Baik } \\
70 \% \leq \mathrm{NR}<80 \% & : \text { Cukup } \\
60 \% \leq \mathrm{NR}<70 \% & : \text { Kurang } \\
0 \% \leq \mathrm{NR}<60 \% & \text { : Sangat Kurang }
\end{array}
$$

Baik.

Maka taraf keberhasilan aktivitas peneliti dan peserta didik berada pada kategori

\section{Hasil Akhir}

Skor tes akhir diurutkan berdasarkan urutan jumlah skor tertinggi ke skor terendah pada skala 100 yang dapat dilihat pada lampiran 23. Berdasarkan hasil tes akhir menunjukkan bahwa terjadi peningkatan pemahaman pada peserta didik, peserta didik tuntas adalah 67,8\%, sedangkan peserta didik tidak tuntas adalah 33,2\%. Hal ini tampak pada rata-rata skor tes akhir lebih baik daripada skor tes awal. Rata-rata skor tes awal adalah 56,8, sedangkan rata-rata skor tes akhir siklus 1 adalah 77,8.

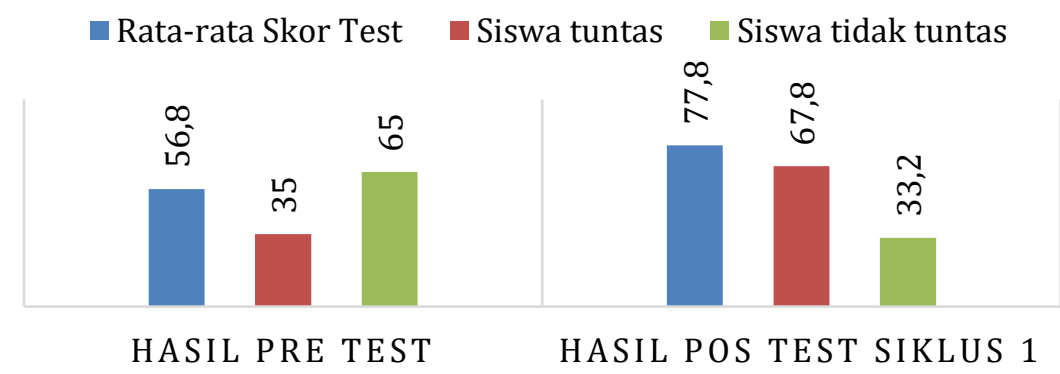

Gambar 1. Peningkatan Hasil Belajar siklus 1 


\section{Refleksi}

Berdasarkan kegiatan refleksi terhadap hasil tes akhir, hasil observasi, hasil wawancara, dan hasil catatan lapangan, maka dapat diperoleh beberapa hal yang perlu diperbaiki pada siklus selanjutnya, yaitu sebagai berikut.

Pertama, Hasil belajar peserta didik berdasarkan skor tes akhir menunjukkan bahan pemahaman peserta didik terhadap materi berada pada kriteria baik. Akan tetapi pada proses pembelajaran peserta didik masih tampak lamban dalam menggunakan metode diskusi dengan sesama teman, sehingga diperlukan pengulangan siklus agar peserta didik lebih terbiasa menggunakan metode diskusi dalam memecahkan kasus untuk menunjang hasil belajar peserta didik.

Kedua, Aktivitas guru telah menunjukkan tingkat keberhasilan pada kriteria sangat baik. Oleh sebab itu, tidak perlu pengulangan siklus untuk aktivitas guru. Guru hanya perlu mengkondisikan agar lebih konsentrasi pada pembelajaran.

Ketiga, Aktivitas peserta didik menunjukkan tingkat keberhasilan pada kriteria sangat baik. Akan tetapi masih perlu melakukan pengulangan siklus karena ada beberapa peserta didik yang kurang aktif pada proses belajar kelompok. Selain itu masih ada peserta didik yang ramai memperbincangkan hal-hal diluar materi pembelajaran sehingga mengganggu konsentrasi peserta didik lain.

Keempat, Kegiatan pembelajaran menunjukkan penggunaan waktu yang sudah sesuai rencana. Oleh sebab itu, tidak diperlukan siklus untuk mengatur penggunaan waktu.

Berdasarkan hasil refleksi dapat disimpulkan bahwa masih diperlukan pengulangan siklus untuk meningkatkan keaktifan peserta didik dalam kegiatan pembelajaran dan melatih peserta didik agar terbiasa dengan tantangan baru yang memerlukan keaktifan dalam pembelajaran.

\section{Kendala dalam Rencana Perbaikan pada Siklus 2}

Pada pelaksanaan siklus 1 peneliti menemukan beberapa kendala dalam pelaksanaan pembelajaran mufrodat. Dengan adanya kendala pada siklus 1 peneliti membuat rencana perbaikan pada siklus 2 agar proses pembelajaran dengan metode merangkai madihin dengan isi mufrodat berjalan dengan baik. Adapun kendala dan rencana perbaikan dapat dilihat pada tabel 3 berikut.

Tabel 3. Kndala dan Rencana Perbaikan pada Siklus 2

\begin{tabular}{|c|c|c|}
\hline No & Kenda Siklus 1 & Rencana Perbaikan Siklus 2 \\
\hline 1. & $\begin{array}{l}\text { Suasana kelas agak ramai saat peserta didik } \\
\text { melakukan kerja kelompok, bahkan ada peserta } \\
\text { didik yang asyik membicarakan hal-hal diluar } \\
\text { materi pembelajaran }\end{array}$ & $\begin{array}{l}\text { Guru atau peneliti berpesan kepada seluruh } \\
\text { peserta didik apabila berdiskusi tidak boleh } \\
\text { ramai dan tidak boleh membicarakan hal-hal } \\
\text { diluar materi pembelajaran }\end{array}$ \\
\hline 2. & $\begin{array}{l}\text { Peserta didik masih ragu-ragu untuk } \\
\text { mengajukan pertanyaan }\end{array}$ & $\begin{array}{l}\text { Guru memberikan kesempatan peserta didik } \\
\text { untuk bertanya dengan pendekatan personal } \\
\text { apabila ada yang belum paham }\end{array}$ \\
\hline 3. & $\begin{array}{l}\text { Peserta didik masih segan dan takut untuk } \\
\text { mengajukan pendapat }\end{array}$ & $\begin{array}{l}\text { Guru berpesan agar peserta didik tidak takut } \\
\text { dalam mengajukan pendapat baik secara } \\
\text { klasikal, kelompok maupun personal }\end{array}$ \\
\hline 4. & $\begin{array}{l}\text { Peserta didik FZ saat pembelajaran tidak mau } \\
\text { berdiskusi dan lebih memilih melakukan } \\
\text { mainannya sendri }\end{array}$ & $\begin{array}{l}\text { Guru melakukan pendekatan personal dengan } \\
\text { memberi motivasi kepada peserta didik FZ } \\
\text { agar mau mengikuti pembelajaran dengan } \\
\text { menggunakan metode madihin dan } \\
\text { bergambung dengan teman sekelompoknya. }\end{array}$ \\
\hline
\end{tabular}



5. Pemahaman peserta didik masih pada kriteria Guru memberikan motivasi kepada peserta cukup dan di bawah KKM (Kriteria didik untuk belajar dengan giat agar hasil Kentuntasan Minimal) yang telah ditentukan belajar peserta didik dapat meningkat. oleh pihak sekolah.

Paparan Data Pelaksanaan Tindakan (Siklus 2)

Pelaksanaan tindakan terbagi ke dalam empat tahap, yaitu tahap perencanaan, pelaksanaan, observasi dan refleksi yang membentuk suatu siklus. Secara lebih rinci, masing-masing tahap dapat dijelaskan sebagai berikut.

\section{Tahap Perencanaan}

Pada tahap ini kegiatan yang dilakukan oleh peneliti adalah: 1) Menyiapkan rencana pembelajaran, 2) Menyiapkan materi pembelajaran yang akan disajikan (mufrodat), 3) Menyiapkan lembar observasi, pedoman wawancara, dan catatan lapangan, 3) Menyusun soal kelompok II dan soal tes individu (soal tes akhir), dan 4) Melakukan koordinasi dengan guru Bahasa Arab mengenai pelaksanaan tindakan.

\section{Tahap Observasi}

Pengamatan dilakukan oleh dua orang pengamat yang sama pada siklus pertama yaitu Bapak selaku guru Bahasa Arab Kelas IV di MIN 9 Banjar sebagai pengamat 1 dan selaku peneliti 2 dan memasuki ruangan kelas IV bersamaan dengan peneliti. Pengamatan dilakukan dengan menggunakan pedoman pengamatan yang telah disediakan oleh peneliti. Jika ada hal-hal penting yang terjadi dalam kegiatan pembelajaran dan tidak ada dalam poin pedoman pengamatan, maka hal tersebut dimasukkan sebagai hasil catatan lapangan.. Nilai yang diperoleh dari pengamat 1 adalah 63 dan nilai yang diperoleh pengamat 2 adalah 64 , sedangkan skor maksimal adalah 70. sehingga nilai yang diperoleh rata- rata adalah $\frac{63+64}{2}=63,5$.

Sesuai taraf keberhasilan yang telah ditetapkan, maka taraf keberhasilan aktivitas peneliti dan peserta didik berada pada kategori sangat baik. Adapun peningkatan keberhasilan aktivitas peneliti dari siklus 1 sampai siklus 2 dapat dilihat pada gambar 2 berikut.

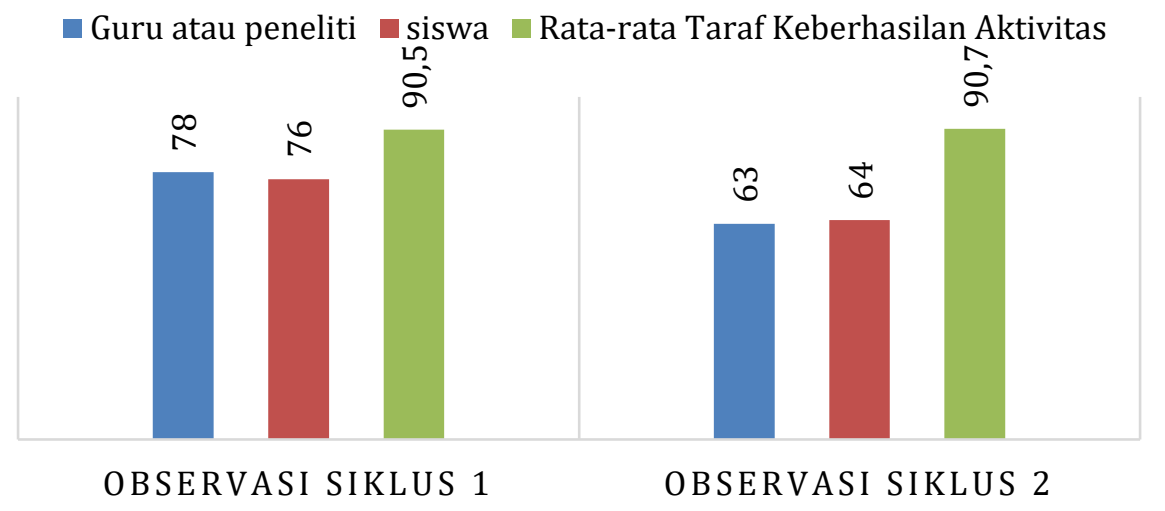

Gambar 2. Peningkatan Keberhasilan Aktivitas Peneliti

\section{Hasil Tes Akhir}

Berdasarkan hasil tes akhir pada siklus kedua menunjukkan bahwa terjadi meningkatan pemahaman pada peserta didik. Hal ini tempat pada peningkatan rata-rata skor kedua adalah 81,2 sedangkan rata-rata skor tes akhir siklus pertama adalah 77,8. adapun peserta didik yang tuntas pada siklus 2 adalah 78,5\%, sedangkan peserta didik 
tuntas pada siklus 1 adalah 67,8\%, dan peserta didik yang tidak tuntas pada siklus 2 adalah $21,5 \%$, sedangkan peserta didik tidak tuntas pada siklus 1 adalah 33,2. Adapun gambar peningkatan hasil belajar dari test awal, post test siklus 1 dan post test siklus 2 dapat dilihat pada gambar 3 .

nata-rata Skor Test $\square$ Siswa tuntas $\square$ siswa tidak tuntas

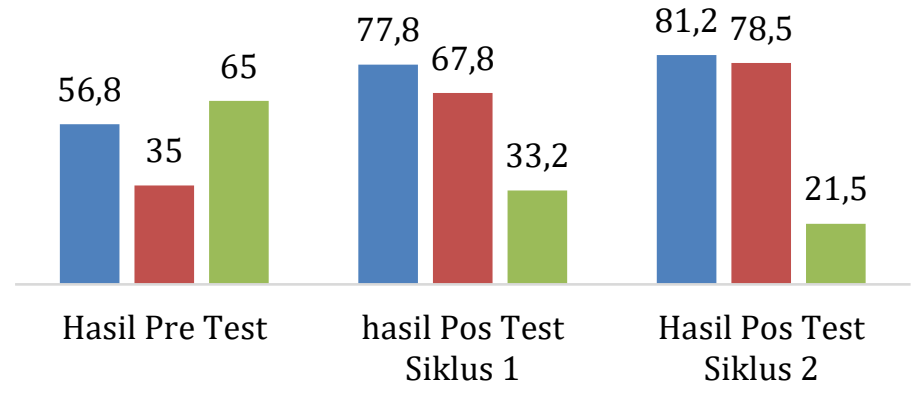

Gambar 3. Peningkatan Hasil Belajar

\section{Refleksi}

Berdasarkan kegiatan refleksi terhadap hasil tes akhir, hasil pengamatan, hasil wawancara, dan hasil catatan lapangan pada siklus kedua, maka dapat diperoleh beberapa hal berikut.

1) Hasil belajar peserta didik berdasarkan skor tes akhir menunjukkan peningkatan yang cukup baik dari tes sebelumnya. Hal ini menunjukkan bahwa pemahaman peserta didik terhadap materi pembelajaran semakin meningkat. Oleh karena itu, tidak perlu pengulangan siklus untuk meningkatkan hasil belajar peserta didik. Aktivitas guru telah menunjukkan tingkat keberhasilan pada kriteria sangat baik. Oleh karena itu, tidak perlu pengulangan siklus untuk aktivitas guru.

2) Aktivitas peserta didik telah menunjukkan tingkat keberhasilan pada kriteria sangat baik. Oleh karena itu tidak perlu pengulangan siklus untuk aktivitas peserta didik.

3) kegiatan pembelajaran menunjukkan penggunaan waktu yang sudah sesuai rencana. Oleh sebab itu, tidak diperlukan pengulangan siklus untuk mengatur waktu.

4) Kegiatan pembelajaran telah menunjukkan keaktifan peserta didik dalam kegiatan pembelajaran. Sehingga tidak diperlukan pengulangan siklus untuk meningkatkan keaktifan peserta didik dalam kegiatan pembelajaran.

Berdasarkan hasil refleksi dapat disimpulkan bahwa setelah pelaksanaan tindakan pada siklus kedua ini tidak diperlukan pengulangan siklus karena secara umum kegiatan pembelajaran telah berjalan sesuai rencana. Peserta didik telah dapat berdiskusi dalam memecahkan masalah sebagai sarana untuk meningkatkan pemahamannya terhadap materi pembelajaran serta meningkatkan keaktifan peserta didik dalam proses pembelajaran.

Berdasarkan hasil perhitungan analisis data dilanjutkan dengan uji Scheffe hasil yang diperoleh adalah sebagai berikut:

1) Terdapat perbedaan prestasi belajar Bahasa Arab bagi peserta didik antara yang menggunakan model pembelajaran Madihin dengan model pembelajaran konvensional $(9,606>4,02)$

2) Terdapat perbedaan prestasi belajar dengan menggunakan metode pembelajaran madihin antara peserta didik yang memiliki motivasi tinggi dan peserta didik yang memiliki motivasi rendah. $(28,547>4,02)$ 


\section{PENUTUP}

Berdasarkan paparan data, temuan penelitian, dan pembahasan pada Bab IV maka kesimpulan penelitian ini adalah sebagai berikut:

1) Langkah-langkah pembelajaran melalui metode mengolah mufrodat dalam bentuk madihin adalah a) Menyampaikan tujuan dan mempersiapkan peserta didik. b) Menyajikan informasi. c) Mengorganisir peserta didik ke dalam tim-tim belajar. d) Membantu kerja tim dan belajar. e) Mengevakuasi. f) Memberikan pengakuan atau penghargaan.

2) Metode mengolah mufrodat dalam bentuk madihin sangat efektif untuk meningkatkan keberhasilan belajar peserta didik. Hal ini dibuktikan dengan tingkat keberhasilan belajar peserta didik yang cukup memuaskan yang dapat diketahui dari indikator keberhasilan yang berupa nilai hasil belajar peserta didik dan proses pembelajaran. Proses belajar sangat menentukan hasil belajar. Nilai rata-rata hasil belajar peserta didik pada pre-test adalah 56,8, pada tes akhir siklus pertama adalah 77,8, sedangkan pada tes akhir siklus kedua adalah 81,2 . Nilai hasil belajar ini tingkat keberhasilanya berada pada criteria sangat baik. Sedangkan ketuntasan peserta didik pada pre-test adalah $35 \%$, pada siklus 1 peserta didik tuntas adalah 67,8 dan siklus 2 adalah $78,5 \%$.

\section{DAFTAR PUSTAKA}

Badan Penelitian dan Pengembanga Daerah. 2007. Urang Banjar dan Kebudayaannya. Banjarmasin: Pustaka Banua

Daryanto. 2014.Pendekatan Pembelajaran Saintifik Kurikulum 2013. Yogyakarta : Gaya Media

Dinas Pemuda dan Olahraga. 2015. Materi Muatan Lokal Kebudayaan Banjar. Banjarmasin: Pustaka Banua

Jumiati, J. (2017). Penerapan Metode Karya Wisata pada Konsep Dasar IPA MI/SD Materi Perkembangbiakan untuk Meningkatkan Motivasi Belajar Mahasiswa PGMI. Muallimuna: Jurnal Madrasah Ibtidaiyah, 2(2), 19-27.

Kemmis, S. \& McTaggart, R. (1997). The action research planner. Deaken University, Victoria.

Suryobroto, B. 1997. Proses Belajar Mengajar di Sekolah. Jakarta: Rineka Cipta

Suwarna. 2006. Pengajaran Mikro. Jakarta : Tiara Wacana

Tajudin.2006.Jatidiri Puisi Rakyat Etnis Banjar di Kalsel. Banjarmasin:Rumah Pustaka Folklor Banjar

Trigan, Djago.1990. Proses Belajar Mengajar Pragmatik, Bandung: Angkasa

Utari, Unga. 2016. Pembelajaran Tematik Berbasis Kearifan Lokal di Sekolah Dasar Dalam Menghadapi Ekonomi Asean ( MEA). Jurnal Teori dan Praktis Pembelajaran IPS. Vol. 1 No.1 April 2016, Issn 2503-1201

Wagiran, 2009. Pengembangan Model Pendidikan kearifan Lokal di wilayah DIY dan mendukung perwujudan Visi Pembangaunan DIY Menuju Tahun 2025, Yogyakarta: Setda Provinsi DIY. 